\title{
STRATEGI PENGEMBANGAN EKONOMI SYARIAH MELALUI PENGUATAN FUNGSI PENGADILAN AGAMA DALAM PENYELESAIAN SENGKETA
}

\author{
(Islamic Economic Development Strategy Through The Strengthening of The Function \\ of Religious Court in Dispute Resolution)
}

\author{
Kelik Pramudya \\ Rumah Sakit Dr. Amino Gondhoutomo Provinsi Jawa Tengah \\ Jl. Brigjend Sudiarto No.347 Semarang, Jawa Tengah, Indonesia \\ Email: kelik_pramudya@yahoo.co.id
}

Naskah diterima: 17 Februari 2018; revisi: 5 April 2018; disetujui: 17 April 2018

\begin{abstract}
Abstrak
Saat ini kegiatan ekonomi syariah berkembang pesat di Indonesia. Perkembangan tersebut diikuti juga dengan bermunculannya sengketa ekonomi syariah. Penyelesaian sengketa ekonomi syariah saat ini menjadi kewenangan Pengadilan Agama, sehingga fungsi Pengadilan Agama perlu diperkuat. Penelitian ini membahas permasalahan bagaimana metode penyelesaian sengketa ekonomi syariah di Indonesia, bagaimana penyelesaian sengketa ekonomi syariah di Pengadilan Agama dan bagaimana strategi penguatan fungsi Pengadilan Agama. Penelitian ini merupakan penelitian hukum normatif yang bersifat deskriptif dengan menggunakan pendekatan perundang-undangan dan pendekatan analitis. Berdasarkan hasil penelitian disimpulkan bahwa penyelesaian sengketa ekonomi syariah menjadi kewenangan Pengadilan Agama. Proses penyelesaian sengketa ekonomi syariah juga didukung dengan regulasi yang mengarah pada proses peradilan yang sederhana, cepat dan biaya ringan, namun selain dukungan regulasi juga diperlukan strategi untuk meningkatkan kualitas kelembagaan Pengadilan Agama. Oleh sebab itu penulis menyarankan perlu dilakukan sosialisasi fungsi dan mengubah stigma tentang Pengadilan Agama.
\end{abstract}

Kata Kunci: ekonomi syariah, sengketa, Pengadilan Agama

\begin{abstract}
Currently, Islamic economic activities are growing rapidly in Indonesia. These developments must be followed by many Islamic Economic disputes.The settlement of this dispute currently is under the authority of the Religious Courts and therefor the function of the court needs to be strengthened. The problems discussed in this study include: how the Islamic Economic dispute resolution methods in Indonesia, how to solve the Islamic economic dispute in the Religious Courts and how the strategy of strengthening the Religious Courts functions.This is a descriptive legal normative research with regulatory and analytical approach. Based on the results of the research, it can be concluded that the Religious Courts has authority over the Islamic economic dispute resolution. The dispute resolution process is supported by regulations that will create a simple, quick and low cost process. Regulatory support is also needed to improve the quality of the Religious Courts. Therefore, the author suggest to socialize the function and change the stigma about the Religious Courts.
\end{abstract}

Keywords: islamic economics, dispute, Religious Court 


\section{A. Pendahuluan}

Sistem ekonomi syariah merupakan sistem ekonomi yang harus diperkuat di Indonesia karena tergolong relatif baru, dibandingkan dengan industri-industri keuangan dan bisnis konvensional. Namun, dalam waktu yang relatif singkat, ekonomi tumbuh dan berkembang sangat pesat. Pada saat ini telah menjadi bagian terpenting dan strategis sebagai salah satu motor penggerak roda perekonomian Indonesia. ${ }^{1}$ Hal yang paling menonjol dalam ekonomi Islam adalah dekatnya sektor riil dan sektor keuangan sehingga sektor keuangan mencerminkan keadaan yang sesungguhnya dari sektor riil, dan sektor keuangan dapat menjadi penggerak sektor riil. Minat masyarakat untuk mempelajari sistem ekonomi syariah semakin meningkat. Bahkan secara legal formal telah berdiri lembaga-lembaga keuangan syariah yang mendasarkan prinsip bagi hasil (profit and loss sharing). Saat ini pula kemudian berdiri bank-bank syariah, baik yang secara khusus mendasarkan pengelolaannya secara syariah murni ataupun bank-bank konvensional yang membuka jendela syariah dalam usaha perbankan yang dijalankannya. Di samping itu berdiri pula lembaga-lembaga keuangan Islam yang lain. ${ }^{2}$ Ekonomi syariah dipandang memiliki karakteristik dan keunikan tersendiri jika dibandingkan dengan peradaban lain. Ekonomi syariah merupakan ekonomi Rabbaniyah,
Ilahiyah, Insaniyah, ekonomi berakhlak dan ekonomi pertengahan.Nilai-nilai tersebut membawa dampak bagi seluruh segi ekonomi di bidang harta berupa; produksi, konsumsi, sirkulasi dan distribusi. ${ }^{3}$

Perkembangan Hukum Ekonomi Syariah di Indonesia diawali dengan munculnya Perbankan Syariah. ${ }^{4}$ Perkembangan ini semakin mendapatkan momentum sejak didirikannya Bank Muamalat pada tahun $1992 .^{5}$ Pendirian bank ini didasarkan pada Undang-Undang Nomor 7 Tahun 1992 sebagai landasan hukum bank kemudian disempurnakan dengan Undang-undang Nomor 10 Tahun 1998 tentang Perubahan atas Undang-undang Nomor 7 Tahun 1992 tentang Perbankan. Dalam undang-undang tersebut diatur dengan rinci landasan hukum serta jenis-jenis usaha yang dapat dioperasikan dan diimplementasikan oleh bank syariah. Undang-undang tersebut juga memberikan arahan bagi bank-bank konvensional untuk membuka cabang syariah atau bahkan mengkonversi diri secara total menjadi bank syariah.

Sistem ekonomi Islam bertujuan untuk mengatur kegiatan ekonomi guna mencapai derajat kehidupan yang layak bagi seluruh individu dalam masyarakat. Sistem ekonomi Islam diseluruh kegiatan dan kebiasaan masyarakat bersifat dinamis dan adil dalam pembagian pendapatan dan kekayaan dengan memberikan hak pada setiap individu untuk

Muhammad Syafi'i Antonio, Bank Syari'ah, Cet. 1 (Jakarta: Gema Insani, 2001), hlm. 4.

Abdul Ghofar Anshori. Pokok-Pokok Hukum Perjanjian Islam di Indonesia (Yogyakarta: Citra Media, 2006), hlm. 5. Muhammad, Aspek Hukum Dalam Muamalat (Yogyakarta: Graha Ilmu, 2007), hlm. 77.

Abdurrahman, Penyelesaian Sengketa Ekonomi Syariah di Indonesia, (Banjarmasin: Makalah Orasi Ilmiah disampaikan pada Pembukaan Kuliah Fakultas Syariah IAIN Antasari, 30 Agustus 2010), hlm. 3.

5 Tira Nur Fitria, "Kontribusi Ekonomi Islam Dalam Pembangunan Ekonomi Nasional,"Jurnal Ilmiah Ekonomi Islam Vol.02, No. 03, (2016):29. 
mendapatkan penghidupan yang layak dan mulia baik di dunia maupun di akhirat nantinya. ${ }^{6}$ Saat ini, kegiatan bisnis syariah tidak hanya mencakup pada lembaga keuangan saja, tetapi pada sektor bisnis lain misalnya: Hotel Syariah, Property Syariah, Restoran Syariah, Salon Syariah, Supermarket dan Swalayan Syariah. Bisnis syariah merupakan segala usaha manusia dalam memenuhi kebutuhan hidup berupa aktifitas produksi, distribusi, konsumsi dan perdagangan baik berupa barang maupun jasa yang sesuai dengan aturan-aturan dan hukumhukum Allah yang terdapat dalam Al Qur'an dan As Sunnah. ${ }^{7}$ Kegiatan bisnis syariah seperti ini tidak hanya kegiatan yang targetnya mendapat keuntungan. Akan tetapi juga memperhatikan pada Hukum Islam sehingga bisnis ini dibatasi dengan hukum halal dan haram.

Berdasarkan Laporan Perkembangan Ekonomi Syariah OJK Tahun 2016, maka selama tahun $2016^{8}$, Industri Jasa Keuangan Syariah Indonesia menunjukkan pertumbuhan yang positif baik dari peningkatan aset perbankan syariah, aset industri keuangan nonbank syariah, nilai Indeks Saham Syariah Indonesia, maupun nilai nominal sukuk korporasi, yang masing-masing tumbuh sebesar 20,28\%, $36,30 \%, 18,62 \%$ dan 19,96\%. Perbaikan kinerja tersebut antara lain dipengaruhi oleh kondisi perekonomian nasional yang kondusif dan sistem keuangan yang stabil. Guna pengembangan keuangan syariah ke depan perlu meningkatkan kapasitas kelembagaan industri keuangan syariah yang lebih efisien, memperluas akses terhadap produk layanan keuangan syariah dan memperbesar pangsa pasar industri jasa keuangan syariah.

Seiring pertumbuhan dan perkembangan kegiatan ekonomi syariah, maka peluang terjadinya sengketa, konflik (dispute) antara para pelaku ekonomi syariah juga semakin besar. Suatu sengketa bermula dari perselisihan paham yang kemudian berlarut-larut tidak terselesaikan antara para subjek hukum yang sebelumnya telah mengadakan hubungan hukum perjanjian, sehingga pelaksanaan hak dan kewajiban yang ditimbulkannya berjalan tidak harmonis. ${ }^{9}$ Semakin banyak dan luas kegiatan bisnis maka frekuensi terjadinya sengketa juga semakin tinggi, dapat diartikan makin banyak pula sengketa yang harus diselesaikan. Setiap jenis sengketa yang terjadi selalu menuntut pemecahan dan penyelesaian yang cepat. Penyelesaian sengketa merupakan cara, prosedur ataupun mekanisme yang ditempuh oleh para pihak guna penyelesaian perselisihan atau konflik atas perbedaan kepentingan mereka. Penerapan prinsip syariah dalam kegiatan usaha diikuti dengan perkembangan lembaga penyelesaian sengketa (dispute resolution) yang ada. Khususnya lembaga peradilan sebagai the last

6 Husain Sahatah, Bangunan Ekonomi yang Berkeadilan Teori, Pratek dan Realitas Ekonomi Islam, (Yogyakarta: Magistra Insania Press, 2004), hlm. 80.

$7 \quad$ Fakhrurazi Reno Sutan, “Kajian Hukum Bisnis Syariah,”Jurnal Misykat al-Anwar, Vol 29, No.1 (2008), http://faiumj.ac.id/jurnal/index.php/MaA16/article/view/62/51 (diakses 16 Februari 2018).

$8 \quad$ OJK, "Laporan Perkembangan Keuangan Syariah 2016," http://www.ojk.go.id/en/berita-dan-kegiatan/publikasi/ Documents/Pages/OJK-Publishes-2016-Islamic-Banking-and-Finance DevelopmentReport/Laporan\%20 Perkembangan\%20Keuangan\%20Syariah\%20\%28LPKS\%29\%202016.pdf (diakses 16 Februari 2018).

9 Suyud Margono,ADR dan Arbitrase Proses Pelembagaan dan Aspek Hukum, (Jakarta: Ghalia Indonesia, 2000), hlm. 12. 
resort bagi pihak-pihak yang bersengketa untuk menyelesaikan sengketa yang dihadapinya. ${ }^{10}$

Perkembangan baru dalam dunia peradilan di Indonesia adalah diberikannya kompetensi penyelesaian sengketa ekonomi syariah kepada peradilan agama. Kompetensi tersebut merupakan suatu tantangan baru bagi aparat hukum di lingkungan peradilan agama, sehingga dibutuhkan kesiapan dalam menangani kasuskasus tersebut. Namun, kemampuan Pengadilan Agama dalam mengadili perkara ekonomi syariah saat ini masih diragukan. Keadaan perkara di pengadilan agama masih didominasi perkara cerai. Selain itu proses peradilan yang masih menggunakan acara peradilan biasa tidak ada bedanya dengan sistem peradilan umum. Oleh karena itu diperlukan pengaturan baru tentang acara peradilan untuk perkara ekonomi syariah. Mahkamah Agung dalam hal ini telah mengeluarkan peraturan yang secara khusus mengatur penyelesaian sengketa ekonomi syariah yaitu Peraturan Mahkamah Agung Nomor 14 Tahun 2016. Oleh karena itu dibutuhkan kesiapan Pengadilan Agama dalam menangani perkara ekonomi syariah, terutama dari segi Sumber Daya Manusia, baik itu Hakim, Panitera dan Jurusita. Mereka harus mengembangkan kompetensi guna menyambut tugas baru yang semakin komplek agar dapat mewujudkan putusan yang berkualitas. Namun, apabila ternyata sistem peradilan perkara ekonomi syariah ini ternyata belum mampu memenuhi rasa keadilan para pihak, maka dibutuhkan formula khusus berupa alternatif penyelesaian sengketa ekonomi syariah. Lembaga penyelesaian sangat penting dalam mendukung pembangunan ekonomi syariah, terlebih ekonomi syariah saat ini masih identik pada sektor perbankan. Terlebih mengingat fungsi pengadilan untuk memberikan perlakuan yang adil dan manusiawi kepada pencari keadilan, memberi pelayanan yang simpatik dan bantuan yang diperlukan bagi pencari keadilan, serta memberikan penyelesaian perkara secara efektif, efisien, tuntas dan final sehingga memuaskan kepada para pihak dan masyarakat.

Berdasarkan latar belakang di atas maka permasalahan yang dibahas dalam penelitian ini adalah bagaimana metode penyelesaian sengketa ekonomi syariah di Indonesia?; bagaimana pelaksanaan penyelesaian sengketa ekonomi syariah di Pengadilan Agama?; dan bagaimana strategi penguatan fungsi Pengadilan Agama dalam penyelesaian sengketa ekonomi syariah?

\section{B. Metode Penelitian}

Penelitian ini termasuk dalam penelitian hukum normatif yaitu penelitian hukum yang dilakukan dengan cara meneliti bahan pustaka yang terdiri dari bahan hukum primer, bahan hukum sekunder, dan bahan hukum tersier. ${ }^{11}$ Penelitian ini bersifat deskriptif dengan menggunakan pendekatan perundangundangan (statute approache) dan pendekatan analitis. Jenis data yang digunakan dalam penelitian hukum ini adalah data sekunder. Data ini tidak diperoleh langsung di lapangan, tetapi diperoleh dari bahan pustaka. Untuk memperoleh bahan-bahan hukum yang diperlukan, dilakukan dengan cara penelusuran, pengumpulan dan pengkajian bahan-bahan

10 Abdul Ghofur Anshori, Peradilan Agama di Indonesia Pasca UU No. 3 Tahun 2006 (Sejarah, Kedudukan \& Kewenangan), (Yogyakarta: UII Press, 2007), hlm. 4-5.

11 Soerjono Soekanto dan Sri Mahmuji.Penelitian Hukum Normatif (Jakarta: Rajawali Pers, 2007), hlm. 14. 
kepustakaan, peraturan perundang-undangan, hasil penelitian, karya-karya ilmiah serta dokumen-dokumen tertulis lainnya.

\section{Pembahasan}

\section{Metode Penyelesaian Sengketa Ekonomi Syariah Di Indonesia}

Dalam konteks hukum di Indonesia, penyelesaian sengketa ekonomi syariah dapat dilakukan melalui dua model, yaitu penyelesaian secara litigasi dan non litigasi. Penyelesaian secara litigasi merupakan wilayah kompetensi pengadilan agama. Untuk pilihan penyelesaian sengketa secara non-litigasi dapat dibagi dua, yaitu melalui arbitrase dan alternatif penyelesaian sengketa.

\section{a. Non Litigasi}

\section{1) Arbitrase}

Penyelesaian sengketa melaui jalur non litigasi diatur dalam satu pasal, yakni Pasal 6 UU No. 30 Tahun 1999 tentang Arbitrase dan Alternatif Penyelesaian Sengketa yang menjelaskan tentang mekanisme penyelesaian sengketa. Arbitrase merupakan cara penyelesaian sengketa perdata di luar pengadilan umum yang didasarkan perjanjian arbitrase secara tertulis oleh pihak yang bersengketa. Perjanjian arbitrase merupakan kesepakatan berupa klausula arbitrase yang tercantum dalam suatu perjanjian tertulis yang dibuat para pihak sebelum atau setelah timbul sengeketa.

Dalam konteks hukum Islam, penyelesaian sengketa melalui arbitrase ini dapat disepadankan dengan istilah tahkim. Kata tahkim ini berasal dari kata kerja hakama yang secara harfiah berarti menjadikan seseorang sebagai penengah bagi suatu sengketa. ${ }^{12}$ Inti arbitrase menurut pandangan Islam adalah penyelesaian sengketa yang terjadi antara para subyek hukum melalui cara-cara damai dengan perantara pihak ketiga, dimana pihak ketiga tersebut berhak untuk mengambil keputusan yang harus diridhoi oleh pihak-pihak yang bersengketa. Di Indonesia terdapat beberapa lembaga arbitrase untuk menyelesaikan berbagai sengketa bisnis yang terjadi dalam lalu lintas perdagangan, antara lain BAMUI (Badan Arbitrase Muamalat Indonesia) yang khusus menangani masalah persengketaan dalam bisnis Islam, sekarang berubah menjadi BASYARNAS (Badan Arbitrase Syariah Nasional) yang menangani masalah-masalah yang terjadi dalam pelaksanaan Bank Syariah. Ada juga BANI (Badan Arbitrase Nasional Indonesia) yang khusus menyelesaikan sengketa bisnis non Islam, dan BAPMI (Badan Arbitrase Pasar Modal Indonesia). Kelebihan penyelesaian sengketa melalui arbitrase sebagai berikut:

a) Cepat dan hemat;

b) Kebebasan dalam memilih arbiter;

c) Terjamin kerahasiaan;

d) Bersifat non-preseden;

e) Kepekaan atau kearifan dari arbiter terhadap perangkat aturan yang akan diterapkan oleh arbiter pada perkara-perkara yang ditanganinya;

f) Kepercayaan dan keamanan, arbitrase memberikan kebebasan dan otonomi sangat luas, juga secara relatif memberikan rasa aman terhadap keadaan tidak menentu dan ketidakpastian sehubungan dengan sistem hukum yang berbeda.

12 Suhrawardi K Lubis. Hukum Ekonomi Islam (Jakarta: Sinar Grafika, 2000), hlm. 184 
Namun, arbitrase pun memiliki kelemahan sebagai berikut:

a) Pada praktiknya, putusan arbitrase tidak dapat langsung dieksekusi, tapi harus meminta eksekusi dari pengadilan.

b) Pengadilan seringkali memeriksa ulang kasus yang ditangani oleh arbiter, sehingga terjadi dua kali proses pemeriksaan sengketa, padahal hal tersebut tidak boleh dilakukan karena putusan yang dikeluarkan oleh arbiter bersifat final dan mempunyai kekuatan hukum tetap serta mengikat para pihak.

\section{2) Alternatif Penyelesaian Sengketa.}

Metode lain dalam penyelesaian sengketa ekonomi syariah adalah Alternative Dispute Resolution (ADR) atau alternatif penyelesaian sengketa. Metode ini mengarah kepada pencapaian sasaran perdamaian. Pemikiran kebutuhan akan lembaga sulh (perdamaian) ${ }^{13}$ pada zaman modern ini tentunya bukanlah suatu wacana dan cita-cita yang masih utopis, melainkan sudah masuk ke wilayah praktis. Hal ini dapat dilihat dengan marak dan populernya Alternative Dispute Resolution (ADR). Bentuk alternatif penyelesaian sengketa antara lain: Konsultasi, Negosiasi, Mediasi, Konsiliasi, Pendapat atau Penilaian Ahli.

Menurut Suyud Margono ${ }^{14}$ kecenderungan memilih Alternative Dispute Resolution (ADR) oleh masyarakat dewasa ini didasarkan atas pertimbangan pertama: kurang percaya pada sistem pengadilan dan pada saat yang sama sudah dipahaminya keuntungan mempergunakan sistem arbitrase dibanding dengan Pengadilan, sehingga masyarakat pelaku bisnis lebih suka mencari alternatif lain dalam upaya menyelesaikan berbagai sengketa bisnisnya yakni dengan jalan Arbitrase, kedua: kepercayaan masyarakat terhadap lembaga arbitrase khususnya BANI mulai menurun yang disebabkan banyaknya klausul-klausul arbitrase yang tidak berdiri sendiri sendiri, melainkan mengikuti dengan klausul kemungkinan pengajuan sengketa ke Pengadilan jika putusan arbitrasenya tidak berhasil diselesaikan. Dengan kata lain, tidak sedikit kasus-kasus sengketa yang diterima oleh Pengadilan merupakan kasus-kasus yang sudah diputus oleh arbitrase BANI. Dengan demikian penyelesaian sengketa dengan cara ADR merupakan alternatif yang menguntungkan. Undang-Undang Nomor 30 Tahun 1999 Tentang Arbitrase dan Alternatif Penyelesaian Perkara mengatur tentang penyelesaian sengketa di luar Pengadilan, yakni melalui konsultasi, mediasi, negosiasi, konsiliasi dan penilaian ahli. Undang-undang ini tidak seluruhnya memberikan pengertian atau batasan-batasan secara rinci dan jelas. ${ }^{15}$

\section{b. Litigasi (Lembaga Peradilan)}

Penyelesaian sengketa ekonomi syariah secara litigasi dilakukan melalui peradilan agama. Lahirnya Undang-Undang Nomor 3 Tahun 2006 tentang Peradilan Agama dan Undang-Undang 21 tahun 2008 tentang Perbankan Syariah menambah tugas dan kewenangan baru bagi

\footnotetext{
Dadan Muttaqiem,Penyelesaian Sengketa Perbankan Syari'ah Di Luar Lembaga Peradilan, dalam Majalah Hukum Varia Peradilan Tahun Ke XXIII NOMOR 266 Januari2008 (Jakarta: IKAHI, 2008) hlm. 60.

14 Suyud Margono, ADR dan Arbitrase,Proses Pelembagaan dan Aspek Hukum, (Jakarta: Ghalia Indonesia, 2000), hlm. 82.

15 Listyo Budi Santoso, Kewenangan Pengadilan Agama Dalam Menyelesaikan Sengketa Ekonomi Syariah Berdasarkan Undang-Undang Nomor 3 Tahun 2006 (Tesis), (Semarang: Universitas Diponegoro, 2009), hlm. 45.
} 
Peradilan Agama untuk menyelesaikan sengketa Ekonomi Syariah yang diajukan oleh masyarakat. Sejak saat itulah muncul paradigma baru bagi Peradilan Agama yaitu apabila sebelumnya Pengadilan Agama yang diidentikan sama dengan Peradilan keluarga, hukum perdata keluarga, maka dengan kewenangannya yang baru dapat mengadili sengketa di bidang ekonomi syariah. Perkara Ekonomi Syariah merupakan perkara di bidang ekonomi syariah meliputi bank syariah, lembaga keuangan mikro syariah, asuransi syariah, reasuransi syariah, reksadana syariah, obligasi syariah, surat berharga berjangka syariah, sekuritas syariah, pembiayaan syariah, penggadaian syariah, dana pensiun lembaga keuangan syariah, bisnis syariah, termasuk wakaf, zakat, infaq, dan shadaqah yang bersifat komersial, baik yang bersifat kontensius maupun volunteer.

Pengadilan Agama menjadi lembaga peradilan tingkat pertama yang bertugas dan berwenang memeriksa, memutus, dan menyelesaikan perkara di tingkat pertama antara orang-orang yang beragama Islam di bidang perkawinan, kewarisan, wasiat dan hibah yang dilakukan berdasarkan hukum Islam serta waqaf, zakat, infaq dan shadaqah serta ekonomi Syariah sebagaimana diatur dalam Pasal 49 Undang-Undang Nomor 50 Tahun 2009. Jangkauan kewenangan mengadili lingkungan peradilan agama dalam bidang ekonomi syariah sudah meliputi keseluruhan bidang ekonomi syariah. Hal ini dapat dipahami dari maksud kata ekonomi syariah itu sendiri yang dalam penjelasan pasal tersebut diartikan sebagai perbuatan atau kegiatan usaha yang dilaksanakan menurut prinsip syariah. Artinya, seluruh perbuatan atau kegiatan usaha apa saja dalam bidang ekonomi yang dilakukan menurut prinsip syariah termasuk dalam jangkauan kewenangan mengadili lingkungan peradilan agama.

\section{Pelaksanaan Penyelesaian Perkara Ekonomi Syariah di Pengadilan Agama}

Penyelesaian sengketa melalui pengadilan (litigasi) telah menjadi kewenangan Pengadilan Agama berdasarkan Pasal 49 Undang-Undang Nomor 3 Tahun 2006 tentang Peradilan Agama. Penetapan Pengadilan Agama sebagai penyelesaian sengketa ekonomi syariah berdasarkan Pasal 49 Undang-Undang Peradilan Agama memberikan perluasan kewenangan kepada Pengadilan Agama. Dengan perluasan kewenangan Pengadilan Agama sebagai pemutus sengketa ekonomi syariah membawa konsekuensi hukum bahwa pengadilan negeri tidak lagi berwenang untuk menyelesaikan sengketa ekonomi syariah. Pasal 49 Undang-Undang Nomor 3 Tahun 2006 menyatakan bahwa "Pengadilan Agama bertugas dan berwenang memeriksa, memutus, dan menyelesaikan perkara-perkara di tingkat pertama antara orang-orang yang beragama Islam di bidang perkawinan, waris, wasiat, hibah, wakaf, zakat, infaq, shadaqah; dan ekonomi syariah". Kemudian dalam Penjelasan Pasal 49 diuraikan lebih lanjut bahwa yang dimaksud "antara orang yang beragama Islam" adalah termasuk orang atau badan hukum yang dengan sendirinya menundukkan diri dengan sukarela kepada hukum Islam mengenai hal-hal yang menjadi kewenangan Peradilan Agama.

Berkaitan dengan tata cara penyelesaian sengketa ekonomi syariah di Pengadilan Agama, pada tahun 2016, Mahkamah Agung telah mengeluarkan Peraturan Mahkamah Agung (PERMA) Nomor 14 Tahun 2016 tentang Tata Cara Penyelesaian Perkara Ekonomi Syariah. PERMA ini untuk menjamin pelaksanaan 
penyelesaian sengketa ekonomi syariah yang lebih sederhana, cepat dan biaya ringan. Berdasarkan PERMA Nomor 14 Tahun 2016 maka perkara ekonomi syariah dapat diajukan dalam bentuk gugatan sederhana atau dengan acara biasa. Pemeriksaan perkara dengan acara sederhana adalah pemeriksaan terhadap perkara ekonomi syariah yang nilainya paling banyak Rp. 200.000.000,00 (dua ratus juta rupiah). Pemeriksaan ini mengacu pada Peraturan Mahkamah Agung Nomor 2 Tahun 2015 tentang Tata Cara Penyelesaian Gugatan Sederhana kecuali hal-hal yang diatur secara khusus.

Penanganan perkara ekonomisyariah dengan cara sederhana mengacu kepada PERMA Nomor 2 Tahun 2015 tentang Tata Cara Penyelesaian Gugatan Sederhana atau biasa dikenal dengan istilah small claims court. Sementara itu, penanganan perkara ekonomi syariah dengan cara biasa tetap mengacu kepada pelbagai peraturan perundang-undangan yang berlaku. Baik dalam hal gugatan sederhana maupun gugatan biasa, penggugat dapat mengajukan perkaranya dengan datang ke kepaniteraan atau melalui pendaftaran elektronik. Bedanya, jika hendak mendaftarkan gugatan sederhana, penggugat cukup mengisi formulir atau blanko gugatan yang disediakan pengadilan. Isinya menguraikan identitas penggugat dan tergugat; penjelasan ringkas duduk perkara (posita); dan tuntutan penggugat (petitum). Selain itu, ketika mendaftarkan perkaranya, penggugat wajib melampirkan bukti surat yang sudah dilegalisasi. Pendaftaran perkara secara elektronik sesungguhnya bukan hal baru lagi di peradilan agama. Sejumlah pengadilan sudah menerapkannya, dengan beberapa varian. Namun, sejauh ini belum ada satupun regulasi yang mengaturnya. ${ }^{16}$ Berikut perbandingan cara penyelesaian sederhana dan cara biasa ${ }^{17}$ :

Tabel.1. Perbandingan Acara Sederhana dan Biasa

\begin{tabular}{lll}
\hline \multicolumn{1}{c}{ Aspek } & \multicolumn{1}{c}{ Cara Sederhana } & \multicolumn{1}{c}{ Cara Biasa } \\
\hline Nilai gugatan & Paling banyak Rp 200 juta & Lebih dari Rp 200 juta \\
\hline Domisili para pihak & $\begin{array}{l}\text { Penggugat dan tergugat berdomisili di } \\
\text { wilayah hukum yang sama. }\end{array}$ & $\begin{array}{l}\text { Penggugat dan tergugat tidak harus } \\
\text { berdomisili di wilayah hukum yang } \\
\text { sama. }\end{array}$ \\
\hline Jumlah para pihak & $\begin{array}{l}\text { Penggugat dan tergugat masing- } \\
\text { masing tidak boleh lebih dari satu, } \\
\text { kecuali punya kepentingan hukum } \\
\text { yang sama Penggugat dan tergugat } \\
\text { masing-masing tidak boleh lebih } \\
\text { dari satu, kecuali punya kepentingan } \\
\text { hukum yang sama. }\end{array}$ & Penggugat dan tergugat masing- \\
\hline Alamat tergugat & Harus diketahui & \\
\hline
\end{tabular}

16 Direktorat Jenderal Peradilan Agama, "Membedah Perma Tata Cara Penyelesaian Perkara Ekonomi Syariah",https://badilag.mahkamahagung.go.id/seputar-ditjen-badilag/seputar-ditjen-badilag/membedahperma-tata-cara-penyelesaian-perkara-ekonomi-syariah (diakses 15 Februari 2018).

17 Ibid. 


\begin{tabular}{|c|c|c|}
\hline Aspek & Cara Sederhana & Cara Biasa \\
\hline Pendaftaran perkara & Menggunakan blanko gugatan & Membuat surat gugatan \\
\hline Pengajuan bukti-bukti & $\begin{array}{l}\text { Harus bersamaan dengan pendaftaran } \\
\text { perkara }\end{array}$ & $\begin{array}{l}\text { Pada saat sidang beragenda } \\
\text { pembuktian }\end{array}$ \\
\hline $\begin{array}{l}\text { Pendaftaran perkara, } \\
\text { penunjukan hakim dan } \\
\text { panitera sidang }\end{array}$ & Paling lama 2 hari & Paling lama hari \\
\hline Pemeriksa dan pemutus & Hakim tunggal & Majelis hakim \\
\hline $\begin{array}{l}\text { Pemeriksaan } \\
\text { pendahuluan }\end{array}$ & Ada & Tidak ada \\
\hline Mediasi & Tidak ada & Ada \\
\hline Kehadiran para pihak & $\begin{array}{l}\text { Penggugat dan tergugat wajib } \\
\text { menghadiri setiap persidangan secara } \\
\text { langsung (impersonal), meski punya } \\
\text { kuasa hukum }\end{array}$ & $\begin{array}{l}\text { Penggugat dan tergugat tidak wajib } \\
\text { menghadiri setiap persidangan secara } \\
\text { langsung (impersonal) }\end{array}$ \\
\hline $\begin{array}{l}\text { Konsekuensi } \\
\text { ketidakhadiran } \\
\text { penggugat pada sidang } \\
\text { pertama tanpa alasan } \\
\text { yang sah }\end{array}$ & Gugatan dinyatakan gugur & Gugatan tidak dinyatakan gugur \\
\hline Pemeriksaan perkara & Hanya gugatan dan jawaban & $\begin{array}{l}\text { Dimungkinkan adanya tuntutan } \\
\text { provisi, eksepsi, rekonvensi, intervensi, } \\
\text { replik, duplik, dan kesimpulan }\end{array}$ \\
\hline $\begin{array}{l}\text { Batas waktu } \\
\text { penyelesaian perkara }\end{array}$ & 25 hari sejak sidang pertama & 5 bulan \\
\hline Penyampaian putusan & $\begin{array}{l}\text { Paling lambat } 2 \text { hari sejak putusan } \\
\text { diucapkan }\end{array}$ & $\begin{array}{l}\text { Paling lambat } 7 \text { hari sejak putusan } \\
\text { diucapkan }\end{array}$ \\
\hline $\begin{array}{l}\text { Upaya hukum dan batas } \\
\text { waktu penyelesaiannya }\end{array}$ & $\begin{array}{l}\text { Keberatan ( } 7 \text { hari sejak majelis hakim } \\
\text { ditetapkan) }\end{array}$ & $\begin{array}{l}\text { Banding ( } 3 \text { bulan), kasasi ( } 3 \text { bulan) dan } \\
\text { peninjauan kembali ( } 3 \text { bulan) }\end{array}$ \\
\hline $\begin{array}{l}\text { Batas waktu pendaftaran } \\
\text { upaya hukum }\end{array}$ & $\begin{array}{l}7 \text { hari sejak putusan diucapkan atau } \\
\text { diberitahukan }\end{array}$ & $\begin{array}{l}14 \text { hari sejak putusan diucapkan atau } \\
\text { diberitahukan }\end{array}$ \\
\hline $\begin{array}{l}\text { Kewenangan pengadilan } \\
\text { tingkat banding dan MA }\end{array}$ & Tidak ada & Ada \\
\hline
\end{tabular}

PERMA Nomor 14 Tahun 2016 menjadi regulasi pertama yang mengakomodasi kemungkinan pengajuan perkara dengan memanfaatkan internet di lingkungan peradilan agama. Mengenai formulir atau blanko gugatan, sebagian pengadilan sudah menyediakannya dan sebagian yang lain belum. Biasanya, blanko- blanko gugatan itu dibuat dalam beberapa versi, mengikuti jenis-jenis perkara yang menjadi kompetensi absolut peradilan agama. Hanya, sejauh ini memang belum ada regulasi yang mengaturnya, sehingga formatnya bervariasi. Bukti-bukti surat dari penggugat, dalam gugatan sederhana, wajib dilampirkan pada surat 
gugatan pada saat mendaftarkan gugatan. Hal ini sejalan dengan konsep dasar small claims court, yang hanya membebankan penggugat untuk mengurai fakta hukum beserta bukti-buktinya, tanpa perlu pusing dengan urusan dasar hukum. Selain itu, keharusan menyediakan bukti-bukti saat pendaftaran bertujuan untuk memberikan kesempatan yang lebih dini kepada tergugat untuk menyiapkan jawaban. Dengan demikian pemeriksaan perkara gugatan sederhana bisa lebih hemat waktu. Jika tergolong small claims court, ketua pengadilan cukup menunjuk satu orang hakim, sedangkan jika termasuk gugatan biasa, ketua pengadilan menunjuk majelis hakim. Hakim tunggal dalam perkara gugatan sederhana dan majelis hakim dalam perkara gugatan biasa harus sudah bersertifikat. Artinya, mereka harus lulus dalam sertifikasi hakim ekonomi syariah yang diselenggarakan MA, berdasarkan PERMA Nomor 5 Tahun 2016. Kalau di PA tersebut belum ada hakim yang bersertifikat, maka ketua pengadilan dapat menunjuk hakim yang pernah mengikuti diklat fungsional ekonomi syariah. ${ }^{18}$

PERMA Nomor 14 Tahun 2016 sangat akomodatif terhadap perkembangan teknologi informasi. Selain melegitimasi pendaftaran perkara online, PERMA yang berisi 15 Pasal pada 11 Bab ini juga memberi peluang pemeriksaan ahli melalui teknologi informasi, misalnya via teleconference. Hal-hal lain berkaitan dengan gugatan sederhana dalam perkara ekonomi syariah yang perlu pengaturan lebih spesifik di antaranya adalah format blanko gugatan sederhana, komponen-komponen dan nominal panjar biaya perkara, register perkara, format penetapan oleh hakim tunggal mengenai kelayakan berperkara secara sederhana, format berita acara sidang dan putusan, juga prosedur dan biaya upaya hukum keberatan. ${ }^{19}$

\section{Penguatan fungsi Pengadilan Agama dalam penyelesaian Sengketa Ekonomi Syariah}

Sebagaimana telah diuraikan di awal bahwa perkembangan hubungan hukum di masyarakat dalam bidang ekonomi, khususnya dalam bidang perjanjian yang menggunakan prinsipprinsip syariah mengalami perkembangan yang signifikan. Perkembangan hukum di bidang ekonomi syariah dan keperdataan lainnya di masyarakat tersebut tentu membutuhkan prosedur penyelesaian yang lebih sederhana, cepat dan biaya ringan, terutama di dalam hubungan hukum yang bersifat sederhana. Pada prinsipnya penyelesaian sengketa ekonomi secara litigasi di pengadilan merupakan tindakan ultimum remedium melalui lingkungan peradilan yang berwenang. Ultimum remedium berupa tindakan terakhir yang dapat ditempuh apabila tidak diperoleh upaya penyelesaian secara kekeluargaan. Saat ini di Indonesia lingkungan peradilan yang mempunyai kewenangan dalam hal penyelesaian sengketa ekonomi yaitu lingkungan peradilan umum dan lingkungan peradilan agama.

Di sisi lain, keberadaan lembaga alternatif merupakan tantangan bagi pengadilan agama dalam peningkatan kualitas. Artinya apakah pencari keadilan lebih memilih Pengadilan Agamadaripadaalternatifpenyelesaian sengketa sangat bergantung dari kesiapan pengadilan agama. Putusan Mahkamah Konstitusi Nomor: 93/PUU-X/2012 telah menganulir Pasal 55 ayat

8 Ibid.

19 Ibid. 
(2) Undang-Undang Nomor 21 Tahun 2008 yang menyebabkan dualisme penanganan perkara antara Pengadilan Agama dan Pengadilan Negeri. Putusan MK tersebut menuntut Pengadilan Agama untuk semakin profesional dalam menangani sengketa ekonomi syariah. Profesionalisme dalam bentuk kesiapan dan kecakapan hakim PA merupakan syarat mutlak untuk mendapatkan kepercayaan publik, khususnya dalam hal penyelesaian sengketa ekonomi syariah. ${ }^{20}$ Guna menjawab kepercayaan publik tersebut khususnya dalam bidang kompetensi Sumber Daya Manusia, Direktorat Jenderal Badan Peradilan Agama menyiapkan hakim yang berkualitas, misalnya dengan menyelenggarakan Training of Trainer bagi hakim baik di tingkat pertama maupun banding di samping menyelenggarakan pelatihan-pelatihan baik di dalam maupun luar negeri. ${ }^{21}$ Selain pelatihan, hal ini dapat juga dilakukan dalam bentuk diskusi terbatas seperti lokakarya, seminar, maupun diskusi internal antara hakim untuk membahas hal-hal aktual di bidang ekonomi syariah dan ekonomi dan bisnis nasional maupun internasional. Pertemuan berkala bagi para pelaku yang terkait dalam lingkup ekonomi syariah untuk membahas soal-soal teknis sangat dibutuhkan. Harus diakui bahwa pemahaman mengenai industri jasa keuangan syariah kepada hakimhakim peradilan agama masih minim. Atas dasar itu, kerjasama untuk memberikan pengetahuan secara menyeluruh mengenai industri jasa keuangan syariah ke para hakim dapat terus dilakukan. Langkah awal bisa dimulai dengan sosialisasikan program ke hakim-hakim pengadilan tinggi di daerah.

Penguatan dalam diri peradilan agama harus terus ditingkatkan. Selain menyelenggarakan pelatihan pada hakim karir, dalam perekrutan Aparatur Sipil Negara (ASN) di lingkungan peradilan agama hendaknya diperhatikan mengenai pengetahuan tentang ekonomi syariah bagi calon ASN. Hal ini karena faktor Sumber Daya Manusia menjadi faktor terpenting dalam kesiapan dan peningkatan mutu pengadilan agama. Perluasan kewenangan Pengadilan Agama untuk menangani sengketa ekonomi syariah, merupakan fenomena baru yang harus dihadapi oleh seluruh jajaran (pegawai dan hakim) Peradilan Agama. Di satu sisi, seluruh hakim Pengadilan Agama memiliki latar belakang pendidikan hukum Islam, yang selama ini tidak menangani sengketa yang terkait dengan ekonomi syariah, sehingga wawasan mereka tentang ekonomi syariah sangat terbatas. Di sisi lain, Pengadilan Agama harus memiliki hakim-hakim khusus yang kapabel dalam menangani sengketa ekonomi syariah. Para hakim juga dituntut untuk memahami segala perkara yang menjadi kompetensinya. Karena hakim dianggap tahu akan hukumnya, sehingga hakim tidak boleh menolak untuk memeriksa perkara dengan dalih hukumnya tidak ada atau kurang jelas. ${ }^{22}$ Sejauh ini asumsi yang berkembang di masyarakat masih mengenal Pengadilan Agama sebagai lembaga penyelesaian perkara cerai. Guna mewujudkan bentuk ideal, pengadilan agama perlahan harus bisa lepas dari kesan ini. Para hakim harus

\footnotetext{
20 Potret Penyelesaian Sengketa Ekonomi Syariah. Majalah Peradilan Agama Edisi 3, Des 2013-Feb 2014.hlm. 18.

21 Ibid.

22 Siti Nurhayati, "Penguatan Peran Hakim Pengadilan Agama Dalam Penyelesaian Sengketa Perbankan Syariah Pasca Putusan Mahkamah Konstitusi Nomor 93/PUU-X/202,”Yudisia, Vol. 7, No. 2 Desember (2006): 325-326.
} 
selalu memperkaya pengetahuan hukum, juga sebagai pertanggungjawaban moral atas klaim bahwa apa yang telah diputus oleh hakim harus dianggap benar (res judicata pro veretatur habetur). Sejalan dengan itu, setiap hakim Pengadilan Agama dituntut untuk lebih mendalami dan menguasai soal perekonomian syariah. Para hakim ini dituntut untuk memahami segala perkara yang menjadi kompetensinya. Hal ini sesuai adagium ius curia novit, karena dalam hal ini hakim dianggap tahu akan hukumnya walaupun perkara tersebut adalah perkara yang baru yang menjadi kewenangannya. Wawasan yang dimiliki hakim Pengadilan Agama terkait penanganan sengketa ekonomi syariah masih terbatas. Wawasannya akan jauh dibanding masalah sengketa perkawinan, waris, wasiat, hibah, waqaf dan sedekah yang selama ini ditanganinya.

Profesi hakim merupakan profesi yang mulia sehingga dalam menjalankan tugas dan kewajibannya dalam menjamin keadilan, hakim harus mampu mengabdikan dirinya kepada kepentingan masyarakat dan bukan kepada kepentingan sendiri. Ke depan salah satu tantangan bagi para hakim Pengadilan Agama adalah mengawal perkembangan ekonomi syariah di Indonesia. Masyarakat tentunya berharap para hakim Pengadilan Agama di seluruh Indonesia dapat lebih mengerti mengenai regulasi dan seluk beluk ekonomi syariah.

Penguatan lain yang perlu dilakukan di Pengadilan Agama adalah mengubah stigma dan pandangan masyarakat tentang Pengadilan Agama. Pengadilan Agama harus terlepas dari kesan sebagai tempat perceraian. Hal ini dapat dilakukan misalnya dengan pemasangan papan informasi tentang penyelesaian sengketa ekonomi syariah di setiap sudut pengadilan, misalnya di pintu gerbang, pintu masuk, ruang tunggu dan tempat parkir. Bahkan apabila perlu, Pengadilan harus menyediakan meja pendaftaran khusus perkara perkara ekonomi syariah dengan tulisan dan prosedur yang jelas dan mudah dibaca pencari keadilan. Langkah-langkah tersebut merupakan salah satu terobosan yang dapat ditempuh guna menunjukkan kepada masyarakat bahwa Pengadilan Agama siap dan mampu menyelesaikan perkara ekonomi syariah.

\section{Penutup}

Penyelesaian sengketa ekonomi syariah di Indonesia dapat dilakukan di luar pengadilan (non litigasi) atau di dalam pengadilan (litigasi). Penyelesaian secara non litigasi ada dua opsi yaitu melalui arbitrase atau melalui alternatif penyelesaian sengketa (ADR), sedangkan untuk litigasi menjadi kewenangan Pengadilan Agama berdasarkan Pasal 49 Undang-Undang Nomor 3 Tahun 2006 tentang Peradilan Agama.

Penyelesaian sengketa ekonomi syariah di Pengadilan Agama mengalami pembaruan. Hal ini setelah terbit Peraturan Mahkamah Agung (PERMA) Nomor 14 Tahun 2016 tentang Tata Cara Penyelesaian Perkara Ekonomi Syariah. PERMA ini untuk menjamin pelaksanaan penyelesaian sengketa ekonomi syariah yang lebih sederhana, cepat dan biaya ringan. Berdasarkan PERMA Nomor 14 Tahun 2016 maka perkara ekonomi syariah dapat diajukan dalam bentuk gugatan sederhana (bernilai di bawah 200 juta) atau dengan acara biasa.

Penguatan Pengadilan Agama dalam rangka melaksanakan penyelesaian sengketa ekonomi syariah dilakukan dengan meningkatkan kualitas Sumber Daya Manusia Pengadilan. Badan Peradilan Umum Mahkamah Agung 
saat ini telah mengadakan berbagai pelatihan baik dalam maupun diluar negeri untuk meningkatkan kompetensi para hakim pengadilan agama dalam hal penanganan ekonomi syariah. Penguatan perlu dilakukan pula dari segi rekrutmen di mana calon ASN yang akan ditempatkan di Pengadilan Agama paling tidak harus mempunyai pengetahuan dasar tentang ekonomi syariah.

Oleh sebab itu disarankan agar Pengadilan Agama perlu membuat kamar khusus dalam perkara ekonomi syariah, di mana harus diisi hakim-hakim yang berkompeten dan memiliki pengetahuan cukup tentang ekonomi syariah agar dapat menghasilkan putusan yang berkualitas dan memenuhi rasa keadilan. Dan juga Pengadilan Agama harus lepas dari kesan sebagai tempat perceraian. Oleh karena itu Pengadilan Agama perlu melakukan sosialisasi dengan memanfaatkan berbagai media untuk menunjukkan kesiapan Pengadilan Agama dalam menangani perkara ekonomi syariah.

\section{Daftar Pustaka}

\section{Buku}

Anshori, Abdul Ghofar. Pokok-Pokok Hukum Perjanjian Islam di Indonesia (Yogyakarta: Citra Media, 2006).

Anshori, Abdul Ghofar, Peradilan Agama di Indonesia Pasca UU No. 3 Tahun 2006 (Sejarah, Kedudukan \& Kewenangan), (Yogyakarta: UII Press, 2007).

Antonio, Muhammad Syafi'i, Bank Syari'ah, Cet. 1 (Jakarta: Gema Insani, 2001).

Burhanuddin, Aspek Hukum Lembaga Keuangan Syariah (Yogyakarta: Graha Ilmu, 2010).

Kara, Muslimin H., Bank Syariah Di Indonesia analisis Kebijakan Pemerintah Indonesia Tentang Perbankan Syariah, (Yogyakarta: UII Press, 2005).

Lubis, Suhrawardi K. Hukum Ekonomi Islam (Jakarta: Sinar Grafika, 2000).

Margono, Suyud, ADR dan Arbitrase Proses Pelembagaan dan Aspek Hukum, (Jakarta: Ghalia Indonesia, 2000).
Muhammad, Aspek Hukum Dalam Muamalat (Yogyakarta: Graha Ilmu, 2007).

Soekanto, Soerjono dan Sri Mahmuji.Penelitian Hukum Normatif (Jakarta: Rajawali Pers, 2007).

\section{Makalah/Artikel/Prosiding/Hasil Penelitian}

Abdurrahman, Penyelesaian Sengketa Ekonomi Syariah di Indonesia, (Banjarmasin: Makalah Orasi Ilmiah disampaikan pada Pembukaan Kuliah Fakultas Syariah IAIN Antasari, 30 Agustus 2010).

Fitria, Tira Nur, "Kontribusi Ekonomi Islam Dalam Pembangunan Ekonomi Nasional,"Jurnal IImiah Ekonomi Islam Vol. 02, No. 03 (2016).

Muttaqiem, Dadan, Penyelesaian Sengketa Perbankan Syari'ah Di Luar Lembaga Peradilan, dalam Majalah Hukum Varia Peradilan Tahun Ke XXIII Nomor 266 Januari 2008 (Jakarta: IKAHI, 2008).

Nurhayati, Siti, "Penguatan Peran Hakim Pengadilan Agama Dalam Penyelesaian Sengketa Perbankan Syariah Pasca Putusan Mahkamah Konstitusi Nomor 93/PUU-X/202,"Yudisia, Vol. 7 No. 2 Desember (2006).

Santoso, Listyo Budi, Kewenangan Pengadilan Agama Dalam Menyelesaikan Sengketa Ekonomi Syariah Berdasarkan Undang-Undang Nomor 3 Tahun 2006 (Tesis), (Semarang: Universitas Diponegoro, 2009).

\section{Internet}

Direktorat Jenderal Peradilan Agama, "Membedah Perma Tata Cara Penyelesaian Perkara Ekonomi Syariah", https://badilag.mahkamahagung. go.id/seputar-ditjen-badilag/seputarditjen-badilag/membedah-perma-tata-cara penyelesaian-perkara-ekonomi-syariah (diakses 15 Februari 2018).

OJK, "Laporan Perkembangan Keuangan Syariah 2016," http://www.ojk.go.id/en/beritadan-kegiatan/publikasi/Documents/Pages/ OJK-Publishes-2016-Islamic-Banking-andFinanceDevelopmentReport/Laporan\%20 Perkembangan\%20Keuangan\%20Syariah\%20 \%28LPKS\%29\%202016.pdf (diakses 16 Februari 2018).

Sutan, Fakhrurazi Reno, "Kajian Hukum Bisnis Syariah,"Jurnal Misykat al-Anwar,Vol 29, No.1 (2008), http://fai-umj.ac.id/jurnal/index.php/ MaA16/article/view/62/51 (diakses 16 Februari 2018). 